\title{
The corneal melting point
}

Eye (2012) 26, 1029-1030; doi:10.1038/eye.2012.136; published online 6 July 2012

Corneal ulceration remains a serious clinical condition. When this occurs with progressive corneal stromal dissolution, there are real risks of permanent sight loss. As ophthalmologists, we have called this destructive process 'corneal melting' ${ }^{1}$

Corneal melting is a common prelude to the development of corneal perforation. This process occurs from conditions such as infections, sterile inflammation, or surgical/ chemical injury to the cornea. ${ }^{1-3}$ Collectively, these conditions are a significant cause for blindness world-wide. ${ }^{4-5}$

From a clinician's standpoint, the immediate concern is how to prevent loss of ocular integrity? Although a variety of surgical and medical therapies are recommended, the clinical effectiveness of these approaches are generally either weak or too slow acting to prevent ocular perforation. ${ }^{1}$

Over the years, several studies have examined the mechanisms of disease. Such studies show the progression of corneal melting to be influenced by the elaboration of excessive tissue degradative proteases. ${ }^{6-7}$ One group of these proteases are the matrix metalloproteinases (MMPs). MMPs are regularly shown to have a role both in infectious and noninfectious causes of corneal tissue destruction. $^{6-8}$

From animal and laboratory studies, a variety of agents or surgical approaches are proposed as potential inhibitors of MMPs. Some of these have been used in human patients. Agents such as EDTA, acetylcysteine, ascorbate, and tetracyclines have all been tried with varying success. ${ }^{1}$ For example, when melting occurs after chemical burns, use of topical ascorbate $10 \%$ eye drops can help to prevent ulceration and promote healing. ${ }^{9}$ Use of amniotic membrane as a surgical bandage can also help in non-healing corneal ulcers. ${ }^{1}$ Antiinflammatory agents such as corticosteroids can be used, but their use is controversial
P Hossain

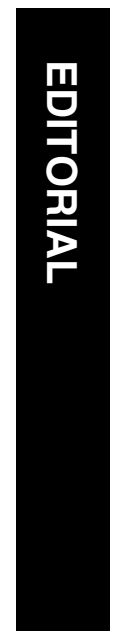

as they can create problems of uncontrolled tissue destruction and impaired wound repair. Some agents, such as non-steroidal anti-inflammatories, can worsen the melting process. ${ }^{10}$

Despite the variable effects of these therapies, animal models of corneal alkali injury and bacterial infection have helped to show potential pathways for therapeutic inhibition. For example, controlling the release of inflammatory mediators and activation of neutrophils appear to have a prominent part in tissue damage. ${ }^{12}$ Resident corneal cells such as keratocytes and infiltrating macrophages are also capable of releasing active MMPs, as well as drive the melting process by the release of proinflammatory cytokines. ${ }^{11-13}$ More recently, animal studies show blockage of growth factors such vasoactive intestinal peptide can be a potent approach to prevent corneal perforation. ${ }^{14}$

In this issue, Ramaesh et al ${ }^{15}$ have revisited the molecular basis of traditional agents by conducting a laboratory-based study using human corneal epithelial explant material. They can measure the effect of acetylcysteine to control the MMP-9 production. Although this study may be limited in its form by being a tissue culture in vitro analysis of MMP activity, the effect of acetylcysteine on MMP-9 production does give a basis for its clinical use. Acetylcysteine is frequently used in patients with filamentary keratitis and in melting ulcers. ${ }^{1}$

However, despite this understanding from the laboratory, therapies like acetylcysteine remain at best weak therapeutic agents. ${ }^{1,16}$ To improve the translation of basic science into more clinically effective therapies, we need to improve our knowledge on the mechanisms that play out in human disease. Currently, from the molecular front, we only have a scanty picture on how clinically relevant molecular mechanisms work in the human condition. The relative contribution of immune cells (such as macrophages or neutrophils) and the relative influence of other cells such as corneal fibroblasts remain to be quantified? Improved
Academic Unit of Clinical Experimental Sciences, Faculty of Medicine, Eye Unit, University of Southampton, Southampton General Hospital, Southampton, UK

Correspondence: P Hossain, Academic Unit of Clinical Experimental

Sciences, Faculty of Medicine, Eye Unit, University of Southampton, Southampton General Hospital, Tremona Road, Southampton S016 6YD, UK

Tel: $+44(0) 238079$ 4270; Fax: + 44 (0)23 80794170 . E-mail: parwez@soton.ac.uk 
human-based models of tissue damage should be developed to enhance our understanding. We need to know what contribution external factors such as toxins from microorganisms or the effects from chemicals have on corneal stromal dissolution? In addition, we need to advance our understanding of the apoptotic processes that influence the survival and death of corneal structural cells. ${ }^{17}$

By improving our understanding of the clinically significant molecular and cellular mechanisms that are involved in the human disease, we are more likely to find successful therapies. Perhaps one day we will be truly able to 'freeze' the melting cornea.

\section{References}

1 Krachmer JH, Mannis MJ, Holland EJ. Cornea (3rd Edition). Mosby Elsevier: Oxford, 2011.

2 Matsubara M, Zieske JD, Fini ME. Mechanism of basement membrane dissolution preceding corneal ulceration. Invest Ophthalmol Vis Sci 1991; 32(13): 3221-3237.

3 Hazlett LD. Corneal response to Pseudomonas aeruginosa infection. Prog Retin Eye Res 2004; 23(1): 1-30.

4 Whitcher JP, Srinivasan M, Upadhyay MP. Corneal blindness: a global perspective. Bull World Health Organ 2001; 79(3): 214-221.

5 Shah A, Sachdev A, Coggon D, Hossain P. Geographic variations in microbial keratitis: an analysis of the peerreviewed literature 2011; $\mathrm{Br}$ J Ophthalmol 95(6): 762-767.

6 Fini ME, Girard MT, Matsubara M. Collagenolytic/ gelatinolytic enzymes in corneal wound healing. Acta Ophthalmol 1992; 202: 26-33.

7 Smith VA, Hoh HB, Easty DL. Role of ocular matrix metalloproteinases in peripheral ulcerative keratitis. $\mathrm{Br} \mathrm{J}$ Ophthalmol (Suppl) 1999; 83(12): 1376-1383.
8 Riley GP, Harrall RL, Watson PG, Cawston TE, Hazleman BL. Collagenase (MMP-1) and TIMP-1 in destructive corneal disease associated with rheumatoid arthritis. Eye 1995; 9: 703-718.

9 Pfister RR, Haddox JL, Lank KM. Citrate or ascorbate/ citrate treatment of established corneal ulcers in the alkaliinjured rabbit eye. Invest Ophthalmol Vis Sci 1988; 29(7): 1110-1115.

10 O’Brien TP, Li QJ, Sauerburger F, Reviglio VE, Rana T, Ashraf MF. The role of matrix metalloproteinases in ulcerative keratolysis associated with perioperative diclofenac use. Ophthalmology 2001; 108(4): 656-659.

11 Pfister RR, Haddox JL, Dodson RW, Deshazo WF. Polymorphonuclear leukocytic inhibition by citrate, other metal chelators, and trifluoperazine. Evidence to support calcium binding protein involvement. Invest Ophthalmol Vis Sci 1984; 25(8): 955-970.

12 Xue ML, Wakefield D, Willcox MD, Lloyd AR, Di Girolamo $\mathrm{N}$, Cole $\mathrm{N}$ et al. Regulation of MMPs and TIMPs by IL-1beta during corneal ulceration and infection. Invest Ophthalmol Vis Sci 2003; 44(5): 2020-2025.

13 Wong YSC, Louafi F, Hossain P. Lipopolysaccharide regulation of toll-like receptor- 4 and matrix metalloprotease-9 in human primary corneal fibroblast cells. Invest Ophthalmol Vis Sci 2011; 52(5): 2796-2803.

14 Jiang X, McClellan SA, Barrett RP, Berger EA, Zhang Y, Hazlett LD. VIP and growth factors in the infected cornea. Invest Ophthalmol Vis Sci 2011; 52(9): 6154-6161.

15 Ramaesh T, Ramaesh K, Riley SC, West JD, Dhillon B. Effects of $N$-acetylcysteine on matrix metalloproteinase-9 secretion and cell migration of human corneal epithelial cells. Eye 2012; 26: 1138-1144.

16 Ralph RA. Tetracyclines and the treatment of corneal stromal ulceration: a review. Cornea 2000; 19(3): 274-277.

17 Vemuganti GK, Reddy K, Iftekhar G, Garg P, Sharma S. Keratocyte loss in corneal infection through apoptosis: a histologic study of 59 cases 2004; BMC Ophthalmol 2004; 4: 16. 